\title{
Does Financial Statement Information Still Matter?
}

\author{
OTUYA, Sunday*1 OFEIMUN, Godwin ${ }^{1}$ AKPORIEN, Fidelis ${ }^{2}$ \\ 1.Department of Accounting \& Finance, Faculty of Humanities, Social and Management Sciences, Edwin Clark \\ University, Kiagbodo, Delta State. \\ 2.Department of Accounting, Faculty of Management Sciences, Nnamdi Azikiwe University, Awka, Anabra
}

State

\begin{abstract}
Financial statements have been used as a medium for communicating corporate performance to the various stakeholders of business organizations. As such, they are expected to have some qualitative characteristics to be able to facilitate this communicative role and provide useful information for investment decision making. To this end, this study was carried out to examine the accounting information relevance on market performance of companies in Nigeria. The study adopted the panel data design and data were obtained from annual reports of companies for the year 2017. The population of the study consisted of all listed industrial and consumer goods companies in Nigeria. A sample size of 37 companies in the industrial and consumer goods sector was randomly selected and utilized for the study. The multivariate regression analysis was adopted as data analytical method. The study using the results of the multivariate regression shows that earning per share; dividends per share and book value per share all have a significant positive relationship with share prices. The study also finds that cash flow from operating activities has a positive but weak correlation with share prices while leverage has a negative and non- significant relationship with share prices. The study concludes that accounting information disclosure in Nigeria has not lost its relevance as investors still use them in making economic and business decisions.
\end{abstract}

Keywords: Value Relevance, Accounting Information, Financial Statements, Share Prices, Earnings.

DOI: $10.7176 /$ RJFA/10-13-03

Publication date:July $31^{\text {st }} 2019$

\subsection{Introduction}

Nigeria's implementation of the International Financial Reporting Standards (IFRS) coupled with growth of its market economy has had a pronounced enlargement in the market capacity, settlement system and management rules of the Nigerian Stock Exchange (NSE). There are a number of factors that can influence a company's share price. These include industrial policy, financial, monetary policy and foreign trade policies. Other macro-economic factors such as investors' expectation, market supervision and financial information are capable of influencing stock prices. However, it is believed that financial information is deemed the most important factor since it provides the specifics on which investors base their investment and portfolio decisions.

Literature on value relevance is concerned with whether financial statement information still matter in valuation of shares of corporate organisations. It is used to ascertain how well accounting numbers are able to measure value. It is instructive to note that a prominent role of the financial statement is to summarize and present a company's transactions and other events in a timely and understandable manner to the various users of accounting information. In this regard, the value relevance of financial statement information is measured in terms of being able to summarize information, irrespective of source, that affects share value (Francis \& Schipper, 1999).

According to Liu and Liu (2007), value relevance is the ability of accounting numbers to summarize the information underlying the stock prices. In their view, value relevance is shown by a statistical association between financial information and prices or returns. Omokudu and Ibadin (2015) define value relevance of accounting information as the degree to which accounting information summarizes the information that is impounded in share prices. They posit that value relevance of such accounting measures, as earnings and book value of assets, could be appraised by the market's reaction to accounting information presented by reporting companies in any period. The reaction of investors (market) to published financial figures is therefore measurable by using share prices as a function of accounting measures such as cashflow, earnings, book value, dividends etc.

There are two contrasting views in the accounting literature as to whether accounting information has lost its value in relation to stock prices. On one hand, Francis and Schipper (1999) and Lev and Zarowin (1999) are of the opinion that accounting information is not value relevant. On the other hand, studies such as (Brinble, 2003; Gjerde, 2007) opine that accounting information is still value relevant. It is in the light of these divergent views that the issue of relevance of accounting information literature is still being largely debated. Omokudu and Ibadin (2015) asserts that the reason why stakeholders believe that traditional financial statements have lost their relevance, is because of the transition from industrialized economy to high-tech, service-oriented economy.

Nigeria is an emerging economy and occupies a key position in the African continent. It is the largest economy in Sub-Saharan Africa (NBS, 2018). The country has a large capital market and a functioning financial system, with well-established professional accounting community pioneered by the Institute of Chartered Accountants of 
Nigeria (ICAN). A few value relevance studies have been conducted (Abubakar, 2012; Titilayo, 2011; Abiodun, 2012; Omokhudu \& Ibadin, 2015; Ijeoma 2015; Uwuigbe, et al 2016; Erin, Olojede \& Ogundele, 2017; Akadakpo \& Mgbame, 2018; Ibanichuka \& Briggs, 2018; Ogbonna \& Briggs, 2018). These studies document evidence on the value relevance of accounting disclosures in Nigeria, although they indicate conflicting results. With these divergent views, we ponder as to whether accounting information is still relevant to investors in decision making. The study also seeks answer to the issue of whether a company's market performance in terms of its share price can be affected by variables such as earnings, dividends, book value, leverage and cash flow. Further, most studies in the developing economies like Nigeria have focused on earnings and dividends without giving much attention to leverage or cash flow. This study makes a clear departure from these prior studies by using a combination of five variables to measure the impact of accounting information on stock prices of quoted firms in Nigeria. This study is therefore motivated by the hunger to address these gaps.

In order to address the research problems, the following questions have been posed in this study:

(i) What is the relationship between earnings per share and share prices of firms listed on the Nigerian Stock Exchange?

(ii) What is the relationship between book value per share and share prices of firms listed on the Nigerian Stock Exchange?

(iii) What is the relationship between dividends and share prices of firms listed on the Nigerian Stock Exchange?

(iv) To what extent does Cash flow from operating activities impact on share prices of firms listed on the Nigerian Stock Exchange?

(v) To what extent does leverage per share impact on share prices of firms listed on the Nigerian Stock Exchange?

\subsection{Literature Review \\ 2.1 Conceptual Clarifications \\ 2.1.1 Accounting Information}

Accounting information as a concept in accounting literature describes the ability of accounting variables as reported in the annual reports to explain the market price of shares. To further clarify the connotation of value relevance, Francis and Schipper (1999), propose four interpretation views of accounting information. These are fundamental analysis view, prediction view, information view and measurement view. In their fundamental analysis interpretation, accounting information is said to be value relevant if it is able to cause changes in stock price trends through its inherent value in a similar way and in the same direction as market prices. The prediction view sees accounting information to be important if it possesses those values that are considered relevant for the future value evaluation of firms and foreseeing the returns of the coming years. In the information and measurement views, accounting information is deemed important if there is a statistical association between financial information and prices or returns. Chang, Chen and Chang (2008) and Abiodun (2012) agree with the information and measurement views as value relevance is seen in terms of the statistical relationship between the financial statements accounting information and the market prices or returns on shares. The concept can therefore be explained in relation to the volume of traded shares or stock price changes due to release of financial information. Given the Francis \& Schipper (1999) information and measurement perspective, this study defines the concept of value relevance of accounting information as ability of accounting figures as published in the financial statements to trigger reactions on investors to invest in new portfolios or maintain existing investment in stock of quoted firms as a result of the inherent connection between financial statement information and stock values.

\subsubsection{Market Price Per Share}

Market price per share $(\mathrm{P})$ is the unit price of share of a listed company. The share price is determined by the forces of market supply and demand. According to Menaje (2012), share price is dependent on the expectations of investors in an efficient capital market hence is highly volatile. O' Hara, Lazdowski, Moldovean \& Samuelson (2000) find that earnings as well as dividend declared by firm are related to market prices of share. Chin \& Hong (2008) argue that if the financial statements contain some new information, reaction will always be expected in the market over the market price of share.

\subsubsection{Earning Per Share}

Earning is a basic accounting measure in study of value relevance of accounting information. It is argued that earning has superiority over other accounting variables since investors always watch out for earnings (Abiodun, 2012). However, investors also watch out for both cash flow and book value of the firm if not satisfied with earnings value. The earnings per share (EPS) is the amount of earnings attributed to a unit of share owned by a shareholder of a company and is a parameter that can be used to measure the financial performance of firms. It is required to be disclosed by companies quoted or about to be quoted in the Stock Exchange (Valix \& Peralta, 2009). The extent to which EPS explain changes in stock prices has been a hot subject of debate in the academic circle. 


\subsubsection{Book Value Per Share}

Book value per share (BVPS) measures the proportion of book value of a company in relation to the number of shares. The book value is usually computed using the historical values in the Statement of Financial Position. It shows the value of the assets of the firm. Extant literatures (Ohlson \& Penman, 1992: Barth, Beaver \& Landsman, 1998; Dontoh, Radhakrishnan \& Ronen, 2004) indicate evidence that points to the fact that there is a significant association between share price and firms' book value relative to earnings. Collins, Maydew and Weiss (1997) in a study found relative value tradeoff between earnings and book value coefficients when earnings are negative, even after controlling for size, risk and earnings persistence.

\subsubsection{Dividends Per Share}

Dividends are part of corporate profits distributed to its ordinary shareholders. Dividend per share (DPS) is the proportion of dividend a shareholder gets per a unit of share held. DPS as a financial accounting metrics is extractable from the income statement. Jones and Danbolt (2005) studied empirical evidence on the determinants of the stock market reaction to production and market diversification announcements using price earnings and dividend yield as variables. The study found that gains are higher for companies with high price earnings low dividend yields and concluded that accounting information is value relevant.

\subsubsection{Cash Flow from Operating Activities Per Share}

One key use of the cash flow measures is that they are expected to provide value relevant information about the growth opportunities of the firm or lack of it. The firm's ability to keep up with its internal needs for cash is shown by its operating cash flow while the investing cash flow gives information about cash inflow or outflow due to purchase or disposal of' assets. The financing activities are indicated by the financial cash flows. Black (1998) provide evidence that cash flows are more value relevant at the growth stages than earnings and also found that at the maturity stage, earnings are more value relevant. Cheng, Liu and Schaefer (1996) find that earnings decrease in value relevance and operating cash flow increase in value relevance with a decrease in earnings performance.

\subsubsection{Leverage per Share}

Leverage is the amount of outside debt owed by the company. Leverage per share (LPS) is the proportion of debt in relation to a unit of share held by shareholders. Dimitrov and Jain (2003) in a study found that change in leverage as an accounting variable is not considered as value relevance. However, Lee and Huh (2010) postulate that the level of debt in a firm's capital structure facilitates the unique roles of earnings and book value in stock valuation. Lee and Huh cited the findings of Barth, Beaver \& Landsman (1998) that the statement of financial position which discloses information on loan decision and liquidation value could facilitate the book value of equity to play a pivotal role on firm's valuation for high-leveraged firms compared to lower-leveraged firms. They maintain that highly leveraged entities would choose more open-minded accounting methods and therefore manipulate earnings. Theoretical Review: The Efficient Market Hypothesis

The study adopts the Efficient Market Hypothesis (EMH) because it explores the usefulness of accounting information in predicting market value of stock. An efficient market is defined as a market where there is a large number of rational, investors actively competing, with each trying to predict future market values of individual securities, and where important current information is almost freely available to all participants (Malkiel, 2011). In an efficient market, stock prices reflect the influence of information based on events that have already taken place as well as anticipated information. Put differently, an efficient market is one in which the actual stock price will be a good assessment of its core value at any point in time.

The EMH emerged as a prominent theory in the mid-1960s and was developed by Fama (1970) when the advent of computers made it possible to compare calculations and prices of hundreds of stocks more quickly and effortlessly. Considering the information reflected in market prices, market efficiency is usually broken down into three levels: Weak, semi-strong, and strong forms of market efficiency. In weak-efficient stock markets, the current stock price reflects all information related to the stock price changes in the past such as data on previous prices, trading volume, etc. In semi-strong efficient markets, market values of stock reveal not only information about past prices but also preset information in public domain such as acquisitions and mergers, accounting policy changes, dividend pay-outs, etc. Finally, in strong efficient markets, current stock prices reflect all possible information which does not necessarily have to be public. (Malkiel, 2011).

\subsection{Methodology}

3.1 Research Design

This study utilizes panel data design. The panel design is a method of studying sample units periodically observed over a defined time frame. Within the social and management sciences, panel design approach has enabled researchers to undertake longitudinal analyses in a large variety of fields thus enabling repeated observations of enough cross-sections (Nachmias and Nachmias, 2009).

\subsection{Population and Sampling}


The population of the study is made up of all 41 industrial and consumer goods firms listed on the Nigerian Stock Exchange as at 31st December, 2018 (NSE Market Report, January 31, 2018). Based on this population, a normal confidence level of $95 \%$ and error tolerance of $0.05 \%$ was used. The final sample size for this study was based on Yamane ${ }^{e e}$ formula (1967). The statistical formula is stated, thus: $n=N / 1+N\left(e^{2}\right)$

Where: $\mathrm{n}=$ sample size

$\mathrm{N}=$ Population size

$\mathrm{e}=$ Level of significance desired

Given that: $\mathrm{N}=41$ and $\mathrm{e}=0.05$, the sample therefore $=41 / 1+\left(41\left(0.05^{2}\right)\right)$ which gives a sample size of 37 companies.

\subsection{Method of Data Collection and Analysis}

Secondary data were used for the study. The secondary data were retrieved from financial statements of the sampled industrial and consumer goods firms for the year 2017. The study made use of the multivariate regression analysis as the data analytical method. Prior to the regression analysis, descriptive and correlational statistics were carried out to address some basic assumptions underlying the regression analysis.

\subsection{Model Specification}

To test the hypotheses developed, the linear and multivariate regression model based on the Ohlson's (1995) model was adopted. It expresses the stock price as a function of the earnings per share and the book value per share.

$$
P_{i t}=\beta_{0}+\beta_{1} E P S_{i t}+\beta_{2} B V_{i t}+e_{i t}
$$

However, based on the Ohlson model, the multivariate regression model has already been tested by the several empirical studies hence the Ohlson model was modified in this study to include dividends, cashflow and leverage to test the relationship between stock price and the accounting variables assuming that the stock price was not normal distribution.

Thus the modified statistical model is as specified below:

Where:

$$
P_{i t}=\beta_{0}+\beta_{1} E P S_{i t}+\beta_{2} B V_{i t}+\beta_{3} D P S_{i t}+\beta_{4} C F_{i t}+L E V_{i t}+e_{i t}
$$

$\mathrm{P}=$ market share price; EPS $=$ Earnings Per share; $\mathrm{BV}=$ Book Value per share DPS $=$ Dividends per share; $\mathrm{CF}=$ Cash flow from operating activities LEV = Leverage

$\mathrm{e}=$ Stochastic or disturbance term. $\mathrm{i}=$ companies $\mathrm{t}=$ Time dimension of the Variables

$\beta_{0}=$ Constant or Intercept. $\beta_{1-5}=$ Coefficients to be estimated or the Coefficients of slope parameters. The expected signs of the coefficients (a priori expectations) are such that $\beta_{1}, \beta_{2}, \beta_{3}, \beta_{4}, \beta_{5}>0$.

\subsection{Operationalization of Variables}

The table below shows the measurement of the variables:

\begin{tabular}{|l|l|c|c|}
\hline Variables & Measurement & $\begin{array}{l}\text { A Priori } \\
\text { Sign }\end{array}$ & Notation \\
\hline Share Price & $\begin{array}{l}\text { To be measured as the closing share price at January 31, 2018 as } \\
\text { published by NSE. }\end{array}$ & + & P \\
\hline Earnings & Net income after tax scaled by the number of shares & + & EPS \\
\hline Book Value & Firms Net worth scaled by the number of shares & BV \\
\hline Dividends & $\begin{array}{l}\text { Measured as dividends declared or paid out during the financial year } \\
\text { scaled by the number of shares }\end{array}$ & + & DPS \\
\hline Cash flow & $\begin{array}{l}\text { Represents the cash flow from operations (operative cash flows) of a } \\
\text { lompany i as it is reported in the statement of cash flows scaled by the } \\
\text { number of shares }\end{array}$ & + & CF \\
\hline Leverage & Measured as total debt scaled by number of shares & + & LEV \\
\hline
\end{tabular}


4.0 Data Analysis and Results

Table 4.1: Descriptive Statistics

\begin{tabular}{|l|c|c|c|c|c|c|}
\hline & P & EPS & BV & DPS & CF & LEV \\
\hline Mean & 23.05 & 31.85 & 92.67 & 0.26 & 44.3 & 10.03 \\
\hline Median & 24.50 & 26.40 & 83.65 & 0.18 & 30.6 & 13.2 \\
\hline Maximum & 163.02 & 43.45 & 189.5 & 1.45 & 68.38 & 123.5 \\
\hline Minimum & 0.70 & -0.56 & 55.65 & 0.24 & 11.15 & 22.1 \\
\hline Std. Dev. & 12.05 & 8.02 & 58.11 & 0.11 & 22.54 & 8.34 \\
\hline Skewness & 0.3456 & -0.124 & 0.185 & 0.086 & 0.367 & 0.937 \\
\hline Kurtosis & 3.2165 & 2.3 & 1.6582 & 2.319 & 1.974 & .0398 \\
\hline Jarque-Bera & 1.6796 & 4.945 & 2.08 & 1.953 & 4.879 & 2.38 \\
\hline Probability & 0.000 & 0.000 & 0.0000 & 0.000 & 0.003 & 0.000 \\
\hline Sum & 1048.45 & 967.8 & 1696.6 & 6.86 & 387.3 & 129.3 \\
\hline Sum Sq. Dev. & 1.585 & 39.85 & $1.60 \mathrm{E}+12$ & 1.576 & 3.27 & 11.34 \\
\hline Observations & 37 & 37 & 37 & 37 & 37 & 37 \\
\hline
\end{tabular}

KEY: P = Share Prices, EPS = Earnings Per Share; BV = Net Book Value Per Share; DPS = Dividend per share; $\mathrm{CF}=$ Cash Flow From Operating Activities Per Share; LEV = Leverage Per Share.

The above displays the descriptive statistics for the data. The $\mathrm{P}$ has a mean of 23.05 with a standard deviation of 12.04. The standard deviation measuring the spread of the distribution is high and indicates considerable dispersion from the mean. This implication is that there are significant variations in share prices of the companies under investigation. Further, the descriptive statistics for EPS shows a mean of 31.85 and standard deviation of 8.02. The low value of standard deviation implies that most of the EPS in the distribution are close to the average value.

The mean value for BV is 92.67. The standard deviation stood at 58.11 and indicates the existence of clustering of the samples around the sample mean. The descriptive statistics of the DPS and CF also shows that while the dividend per share for the sampled companies averaged .026, the mean for CF showed 44.30. Results from the table further indicate standard deviation of 0.11 and 22.50 respectively for DPS and CF. The high value of the standard deviation also means that the distribution is inclusive of companies with varying degrees of dividend policy and cash flow management. Finally, the mean value for LEV is 10.03 as the standard deviation stood at 8.34

The analysis of the descriptive statistics indicates that all the variables satisfy the normality criterion as their respective Jarque-Bera were all significant and the p-values less than the 5\% significant level.

Table 4.2 Correlation Table

\begin{tabular}{|c|c|c|c|c|c|c|c|}
\hline & & $\mathbf{P}$ & EPS & BV & DPS & $\mathrm{CF}$ & LEV \\
\hline $\begin{array}{l}\text { Pearson } \\
\text { Correlation }\end{array}$ & $\begin{array}{l}\text { P } \\
\text { EPS } \\
\text { BV } \\
\text { DPS } \\
\text { CF } \\
\text { LEV }\end{array}$ & $\begin{array}{c}1.000 \\
.765 \\
.631 \\
.835 \\
.343 \\
-.034\end{array}$ & $\begin{array}{l}1.00 \\
.234 \\
-.070 \\
.213 \\
.110\end{array}$ & $\begin{array}{r}1.00 \\
.295 \\
.319 \\
-.329\end{array}$ & $\begin{array}{l}1.00 \\
.434 \\
.110\end{array}$ & $\begin{array}{l}1.00 \\
.326\end{array}$ & 1.00 \\
\hline $\begin{array}{l}\text { Sig. } \\
\text { (1-tailed) }\end{array}$ & $\begin{array}{l}\text { P } \\
\text { EPS } \\
\text { BV } \\
\text { DPS } \\
\text { CF } \\
\text { LEV }\end{array}$ & $\begin{array}{l}.003 \\
.023 \\
.000 \\
.086 \\
.150\end{array}$ & $\begin{array}{c}- \\
.000 \\
.003 \\
.000 \\
.000\end{array}$ & $\begin{array}{l}-.000 \\
.003 \\
.003\end{array}$ & $\begin{array}{r}- \\
.000 \\
.000\end{array}$ & $\begin{array}{l}- \\
.003\end{array}$ & - \\
\hline
\end{tabular}

*Significant at $\mathrm{p}<0.05$

KEY: $\mathrm{P}=$ Share Prices, EPS = Earnings Per Share; BV = Net Book Value Per Share; DPS = Dividend per share; $\mathrm{CF}=$ Cash Flow From Operating Activities Per Share; LEV = Leverage Per Share..

The table shows the relationship among the variables. $\mathrm{P}$ is observed to correlate positively with EPS $(\mathrm{r}=0.765)$, BV $(r=0.631)$, DPS $(r=0.835)$ and CF $(r=0.343)$. The correlation also shows that SP has a negative relationship with LEV ( $\mathrm{r}=-0.034)$. Further, the table also indicates that EPS is positively correlated with BV $(\mathrm{r}=0.234), \mathrm{CF}$ $(\mathrm{r}=0.070)$ and LEV $(\mathrm{r}=0.110)$ but negatively correlated with DPS $(\mathrm{r}=-0.070)$. BV is also observed to have a positive relationship with DPS $(\mathrm{r}=0.295)$ and CF $(\mathrm{r}=0.319)$; and a negative correlation with LEV $(\mathrm{r}=-0.329)$. DPS has a positive correlation with $\mathrm{CF}(\mathrm{r}=0.434)$ and $\mathrm{LEV}(\mathrm{r}=0.110)$ while $\mathrm{CF}$ has a positive correlation with $\operatorname{LEV}(\mathrm{r}=0.326)$. 
Table 4.3: Regression Statistics

\begin{tabular}{|cl|l|l|l|l|l|l|l|l|l|}
\hline Model & & Sum of Squares & Df & Mean $^{2}$ & F & Sig & R & $\mathrm{R}^{2}$ & Adj. $^{2}$ & SEE \\
\hline 1 & Regression & 12.784 & 1 & 12.784 & 21.8 & $.000(\mathrm{a})$ & $.905(\mathrm{a})$ & .819 & .789 & .9445 \\
& Residual & 28.080 & 48 & .585 & & & & & & \\
& Total & 40.864 & 49 & & & & & & & \\
\hline
\end{tabular}

a Predictors: (Constant), EPS, BV, DPS, CF, LEV

b Dependent Variable: P

The summarized regression results in table 4.3 shows that the multiple regression model is highly significant. The co-efficient of determination or $\mathrm{R}^{2}$ is .819 . This shows that the model is able to explain about 82 percent of the variations of the share prices. The adjusted $\mathrm{R}^{2}$ gives .789 further affirming that 78.90 percent of the variations in the dependent variable of the model are explained by the variations in the independent variables. Also, the fratio of 21.8 shows that the predictor variables are very significantly related with the response variables. The regression model obtained for this study can therefore be used to forecast stock prices fairly.

\subsection{Discussion of Findings}

Firstly, the study finding indicates the existence of a positive and significant association between earnings per share and share prices of industrial and consumer goods firms listed on the Nigerian Stock Exchange. The results suggest that higher earnings per share disclosures affect the informativeness of financial estimates and which in turn improve on stock prices. This finding is consistent with Akadakpo and Mgbame (2018), Uwuigbe, et al (2016), Ijeoma (2015), Adaramola and Oyerinde (2014), Barth, Beaver and Landsman (1998) and Collins, Kothari and Rayburn (1987).

Secondly, from the regression estimates and correlation statistics presented the study also finds that a significant statistical relationship exists between book value per share and share prices of firms listed on the Nigerian Stock Exchange. The study findings in this regards suggests that as the net book value per share of a company improves, the disclosure of this information will enhance the price of the shares of the company. This finding also conforms to the studies earlier conducted by (Barth, Beaver \& Landsman, 1998 and Omokhudu \& Ibadin, 2015; Ijeoma, 2015).

Thirdly, the study also finds that dividends declared or paid by companies and disclosed in the annual reports have a significant impact on the prices of the share of the company. This can be observed from the relationship between dividends per share and share price of surveyed companies for the period under review. Gjerde, Knivsfla and Saettem, (2005), Melissa (2013), Khurana, and Kim (2003) and Mohammadi (2012) in their studies have found positive relationship between dividends and share prices.

Fourthly, the study also has evidence to suggest that a weak and insignificant relationship exist between cash flow from operating activities and share prices. This is consistent with findings of Cheng, Liu and Schaeffer (1996).

Finally, the study also finds a negative but insignificant relationship between leverage and share prices. Though, the finding was not significant at $5 \%$, which could suggest the more debts a company has in its financial statement will negatively impact on the value of stock of the company. This finding aligns with Lee and Huh (2010) but contrasts with Dimitrov and Jain (2003) that find leverage as not value relevant.

\subsection{Conclusion}

The study was carried to examine financial statements accounting information relevance on share prices of quoted companies in Nigeria. The study using the results of the multiple regression analysis based on data obtained from sampled companies' financial reports shows that earning per share, dividends per share and net book value per share all have significant positive relationship with share prices. This implies that accounting information disclosure is relevant and affects the value of shares of quoted companies. The study also finds that cash flow from operating activities has a positive but weak correlation while leverage has a negative insignificant relationship with value of stock of the quoted companies. The study concludes that accounting information disclosure in Nigeria has not lost its relevance as investors still use them in making economic and business decisions.

\subsection{Recommendations}

Based on the findings of this study, it is recommended that management of listed firms should pay attention to the magnitude of earnings reported in their financial statements. Since earnings have been demonstrated to be positively associated with stock values, firms should undertake innovation and investments that generate more earnings. Since dividend and cash flow payment and position influence share prices, management must ensure regular payment of dividends and ensure effective working capital management so as to have a sustainable cash flow from operations.

\section{References}

Abiodun, B.Y. (2012). Significance of accounting information and corporate values of firms in Nigeria. Research 
Journal in Organisational Psychology \& Educational Studies. 1(2), 105-113. www.emergingresource.org)

Abubakar, S. (2012). Value relevance of accounting information of listed new economy firms in Nigeria: An empirical investigation using Ohlson model. Retrieved from kubanni.abu.edu.ng:8080/.../value\%20relevance\%20of\%20accounting\%.pdf

Akadakpo, B. A. \& Mgbame, M. C. (2018). Value relevance of accounting information: The moderating effect of timeliness. Accounting \& Taxation Review, 2(1), 122-135

Barth, M., Beaver, W.H. and Landsman, W.R. (1998). Relative valuation roles of equity book value and net income as a function of financial health. Journal of Accounting and Economics, 6(3), 45.

Cheng A., Liu C. \& Schaeffer T. (1996). Earnings permanence and the incremental information content of cash flows from operations. Journal of Accounting Research 34, 173- 181

Collins, D.W., Maydew, E.L. \& Weiss, I.S. (1997). Changes in the value-relevance of earnings \& equity book values over the past forty years, Journal of Accounting and Economics, 24.

Collins, D., Kothari, S. \& Rayburn, J. (1987). Firm size and the information content of prices with respect to earnings. Journal of Accounting and Economics, 9, 111-138.

Dontoh, A., Radhakrishnan, S., \& Ronen, J. (2004). The declining value-relevance of accounting information and non-information-based trading: An empirical analysis. Contemporary Accounting Research, 21(4), 795-812.

Erin, O., Olojede, P., \& Ogundele', O. (2018). Value relevance of accounting data in the pre and post IFRS Era: Evidence from Nigeria. International Journal of Finance and Accounting, 6(4), 95-103.

Fama, E.F., (1970). Efficient capital markets: A review of theory and empirical work. The Journal of Finance, $25(2), 383-417$

Francis, J. \& Schipper, K. (1999). Have financial statements lost their relevance? Journal of Accounting Research, 37 (2), 319-352.

Gjerde, O., Knivsfla, K. H. \& Saettem F. (2003). The Value Relevance of Financial Reporting on the Oslo Stock Exchange. Institute for Research in Economics and Business Administration, Bergen.

Gjerde, O., Knivsfla, K. \& Saettem, F. (2005). The value relevance of financial reporting on the Oslo stock exchange over the period 1964-2003. Discussion paper 2005/23, Department of Finance and Management Science, Norwegian School of Economics and Business Administration.

Ibanichuka, E. A.L. \& Briggs, A. C. (2018). Audit reports and value relevance of accounting information: Evidence from commercial banks in Nigeria. Indian Journal of Finance and Banking, 2( 1), 44-62

Ijeoma, N.B. (2015). Value relevance of accounting information on share prices of listed firms. Social and Basic Science Research Review, 3(10), 328-344.

Lee, K, J., \& Huh, S-K. (2010). Firms financial leverage and its impact on differential roles of earnings and book value for equity valuation. Pan-Africa Journal of Business Research, 1(1), 41-59.

Liu, J., \& Liu, C. (2007). Value relevance of accounting information in different stock market segments: the case of Chinese A-, B-, and H-shares. Journal of International Accounting Research, 6(2), 55-81

Malkiel, B. G. (2011). The efficient-market hypothesis and the financial crisis. Rethinking Finance: Perspectives on the Crisis (Proceedings of a Conference). Russel Sage Foundation

Menaje, P. M. (2012). Impact of selected financial variables on share price of publicly listed firms in Philippines. American International Journal of Contemporary Research, 2(9), 98-104.

Mohammadi, A. (2012). The investigation of relationship between accounting information and the value of companies (Case Study), http://www.icndbm.com/pdf/129.pdf

Nachmias, F. \& Nachimias, D. (2009). Research methods in the Social Science (5th Edition). United Kingdom: Hodder Educational Books.

National Bureau of Statistics, (2018). Sector statistics. Available from http://www.nigerianstat.gov.ng/.

Nigerian Stock Exchange (2018) Market Reports. Available online atwww.nigerianstockexchange.com/Issuerssection/listing...company/industry

O’Hara, T., Lazdowski, C., Moldovean, C. \& Samuelson, S. (2000). Financial Indicators of stock performance: West Haven. American Business Review

Ohlson, J.A. (1995). Earnings, Book Values, and Dividends in Equity Valuation. Contemporary Accounting Research, 11 (2), 661-687.

Omokhudu, O.O., \& Ibadin, P.O. (2015). The value relevance of accounting information: evidence from Nigeria. Accounting and Finance Research, 43, 20-30.

Oshodin, E. \& Mgbame, C. O. (2014). The comparative study of value relevance of financial information in the Nigeria banking and petroleum sectors. Journal of Business Studies Quarterly, 6(1), 42-54.

Uwuigbe, O.R., Uwuigbe, O., Jafaru, J., Igbinoba, E.E., \& Oladipo, O.A. (2016). Value relevance of financial statements and share price: a study of listed banks in Nigeria. Banks and Bank Systems, 11(4), 135 - 143

Yamane, T. (1967). Elementary Sampling Theory. Englewood Cliffs, N.J. Prentice-Hill, Inc. 